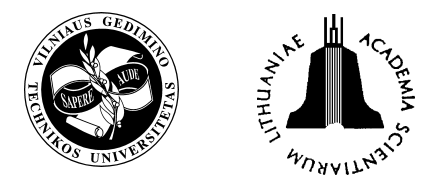

\title{
ENERGY SAVINGS EFFICIENCY IN PUBLIC BUILDINGS UNDER MARKET CONDITIONS IN RUSSIA
}

\author{
Oleg Samarin', Kirill Lushin ${ }^{2}$, Sabina Paulauskaité丶 \\ 1, 2 Moscow State Civil Engineering University, Jaroslavskoje road, 26, 129337 Moscow, Russia \\ ${ }^{3}$ Vilnius Gediminas Technical University, Saulètekio al. 11, LT-10223 Vilnius, Lithuania \\ E-mail: ${ }^{1}$ samarin1@mtu-net.ru ; ${ }^{2}$ tgvmgsu@mail.ru; ${ }^{3}$ spaul@ap.vtu.lt
}

Received 4 September 2006; accepted 15 February 2007

\begin{abstract}
The example of energy effect integrated assessment for public building using the methods proposed by Russian Scientific and Technical Civil Engineers Organisation is presented. Comparative analysis of energy saving scopes for some public buildings with calculation of a recoupment for the specified cases using investments and operating costs discounting has been made.
\end{abstract}

Keywords: energy saving, comparative efficiency, combined method, investments reduction.

\section{Introduction}

It is well known that lack of fossil fuel and rise of energy costs lead the issue of energy saving in buildings in the row of urgent problems in most parts of the world. Obviously, one of the best measures to achieve the results in energy saving is to provide a complex development and researches in that field.

Buildings renovation may be developed in different ways. Taking into account only economical and energy saving aspects of that issue is not acceptable because a wide multipurpose role of civil engineering exists in our days. Trying to analyse building in a complex way is quite an actual method for many authors $[1,2]$. Complex method of application energy saving design in everyday practice is shown in [3, 4]. Energy saving effect comparison for a real and developing object is presented in [5].

\section{Methods}

\subsection{Objects for investigation}

The research series have been made with a purpose to estimate the energy saving effect of special improvements in several civic buildings in Moscow. The first one is Depository of Kolomenskoe museum (object 1). The next one is medical centre of social and health rehabilitation (object 2). And the last one is the Multifunctional office block (object 3). The research results got by the authors of this paper were practically verified by students S. Barvinsky, I. Sadikova, A. Anisimov during their work on diploma papers [6].

\subsection{Comparison of variants}

As the basis for analysis, the principles developed by experts of Russian Scientific and Technical Civil Engineers Organisation (Rus. Sci. Tech. C. E. O.) were used [7]. Authors took an active part in all stages of this research. Technique refers to the data of that standard and is provided with matching of a building general annual power consumption the two variants of building envelope heat protection and the two different engineering systems types and schemes. Finally, a summary of total cost of all energy saving measures was made.

According to this method the costs and efficiency of energy saving measures are remain flexible within wide limits and could be easily manipulated by customer and contractor in connection with the most modern needs for each specific case. It provides for both a better way to control and manage investments at all stages of building construction and a possibility to maintain and achieve high results of energy saving.

The set of data for energy saving measures with a complex investment optimisation are shown in Tables 1 and 2.

The basic variant (var 1) for analysis was a building 
Table 1. Energy indexes

\begin{tabular}{|c|c|c|c|c|c|c|c|}
\hline \multirow{3}{*}{ Parameter } & \multirow{3}{*}{ Units } & \multicolumn{6}{|c|}{ Value } \\
\hline & & \multicolumn{2}{|c|}{ Object 1} & \multicolumn{2}{|c|}{ Object 2} & \multicolumn{2}{|c|}{ Object 3} \\
\hline & & Var 1 & Var 2 & Var 1 & Var 2 & Var 1 & Var 2 \\
\hline Number of people (according to the design) & Persons & \multicolumn{2}{|c|}{300} & \multicolumn{2}{|c|}{580} & \multicolumn{2}{|c|}{1875} \\
\hline Glazing area & $\mathrm{m}^{2}$ & \multicolumn{2}{|c|}{747} & \multicolumn{2}{|c|}{1073} & \multicolumn{2}{|c|}{1549} \\
\hline Area of external walls (without windows) & $\mathrm{m}^{2}$ & \multicolumn{2}{|c|}{1759} & \multicolumn{2}{|c|}{2503} & \multicolumn{2}{|c|}{3479} \\
\hline Roof area & $\mathrm{m}^{2}$ & \multicolumn{2}{|c|}{2397} & \multicolumn{2}{|c|}{2884} & \multicolumn{2}{|c|}{3506} \\
\hline Floor area over the basement & $\mathrm{m}^{2}$ & \multicolumn{2}{|c|}{2992} & \multicolumn{2}{|c|}{2884} & & \\
\hline Coefficient of glazing & - & & & & & & \\
\hline Heated area & $\mathrm{m}^{2}$ & & & & & & \\
\hline Heated volume & $\mathrm{m}^{3}$ & & & & & & \\
\hline Mean temperature of internal air [15-16] & ${ }^{\circ} \mathrm{C}$ & & & & & & \\
\hline Mean temp. of ext. air during the heat season [8] & ${ }^{\circ} \mathrm{C}$ & & & & & & \\
\hline Duration of the heat season [8] & day & & & & & & \\
\hline Conventional heat season total characteristic & $10^{3} \cdot \mathrm{deg} \cdot \mathrm{h}$ & & & & & & \\
\hline Thermal resistance of external walls & $\mathrm{m}^{2} \cdot \mathrm{K} / \mathrm{W}$ & 0,755 & 2,13 & 0,96 & 2,51 & 0,92 & 2,77 \\
\hline Roof thermal resistance & $\mathrm{m}^{2} \cdot \mathrm{K} / \mathrm{W}$ & 0,961 & 2,52 & 1,72 & 3,81 & 1,66 & 3,70 \\
\hline Thermal resistance of the floor over the basement & $\mathrm{m}^{2} \cdot \mathrm{K} / \mathrm{W}$ & 1,269 & 3,06 & 1,44 & 3,34 & 1,38 & 3,25 \\
\hline Thermal resistance of the windows & $\mathrm{m}^{2} \cdot \mathrm{K} / \mathrm{W}$ & 0,42 & 0,56 & 0,49 & 0,71 & 0,42 & 0,54 \\
\hline Summary area of the external enclosures & $\mathrm{m}^{2}$ & & & & & & \\
\hline Coefficient $n$ of the external wall [8] & - & & & & & & \\
\hline Coefficient $n$ of the roof [8] & - & & & & & & \\
\hline Coefficient $n$ of the floor over the basement [8] & - & & & & & & \\
\hline Coefficient $n$ of the windows [8] & - & & & & & & \\
\hline Factor of compactness & $\mathrm{m}^{-1}$ & & & & & & \\
\hline Heat losses through enclosures & MWh/y & 1186 & 357 & 1216 & 616 & 1571 & 871 \\
\hline Calculated air flow (according to design) & $\mathrm{m}^{3} / \mathrm{h}$ & & & & & & \\
\hline Air flow ratio (during working hours) & $\mathrm{h}^{-1}$ & & & & & & \\
\hline Air flow ratio (during free hours) & $\mathrm{h}^{-1}$ & & & & & & \\
\hline Effectiveness factor of heat utilisation devices & - & 0 & 0,5 & 0 & 0,5 & 0 & 0,5 \\
\hline Factor of account of opposing heat flow & - & 0,8 & 0,7 & 0,8 & 0,7 & 0,8 & 0,7 \\
\hline Working hours & $\mathrm{h} /$ day & & & & & & \\
\hline Effective air flow ratio & $\mathrm{h}^{-1}$ & 1,33 & 0,75 & 0,86 & 0,52 & 0,86 & 0,52 \\
\hline Energy expenditures for warming up the ventil. air & MWh/y. & 1566 & 883 & 1366 & 826 & 1763 & 1062 \\
\hline Norm of the hot water charge per average day [17] & 1/day & & & & & & \\
\hline Factor of reduction of the hot water charge & - & 1 & 0,94 & 1 & 0,94 & 1 & 0,94 \\
\hline Energy expenditures for hot water supply & MWh/y & 20,5 & 19,3 & 39,7 & 37,3 & 128,3 & 121 \\
\hline Capacity of electric drives of engineering systems & $\mathrm{kW}$ & & & & & & \\
\hline Factor of demand for electric drives [18] & - & & & & & & \\
\hline Energy consumption by electric drives & MWh/y & & & & & & \\
\hline Mean load on illumination and electric devices [12] & $\mathrm{kW} /$ pers. & & & & & & \\
\hline Capacity of illumination and electric devices & $\mathrm{kW}$ & & & & & & \\
\hline Factor of demand for illumin. and el. devices [18] & - & & & & & & \\
\hline Electricity consumption of illumin. and el. devices & MWh/y & & & & & & \\
\hline Specific household heat ingress (on $1 \mathrm{~m}^{2}$ heat. area) & $\mathrm{W} / \mathrm{m}^{2}$ & & & & & & \\
\hline Household heat ingress & MWh/y & & & & & & \\
\hline Shading factor of the light aperture [20] & - & 0,65 & 0,50 & 0,65 & 0,50 & 0,65 & 0,50 \\
\hline Factor of relative penetration of solar radiation [20] & - & 0,57 & 0,83 & 0,57 & 0,83 & 0,57 & 0,83 \\
\hline Heat ingress from solar radiation through windows & MWh/y & 34,6 & 38,8 & 46 & 51,7 & 71,7 & 80,3 \\
\hline Summary heat ingress & MWh/y & - & 511 & - & 772 & - & 798 \\
\hline The annual power operational characteristic & $\mathrm{kWh} / \mathrm{m}^{2} \cdot \mathrm{y}$ & 355 & 132 & 326 & 121 & 261 & 103 \\
\hline
\end{tabular}


Table 2. Comparative effectiveness of the energy saving measures

\begin{tabular}{|c|c|c|c|c|c|c|}
\hline \multirow{3}{*}{ Energy saving measures } & \multicolumn{6}{|c|}{ Decrease of energy consumption } \\
\hline & \multicolumn{3}{|c|}{$\mathrm{kWh} /\left(\mathrm{m}^{2} \cdot\right.$ year $)$} & \multicolumn{3}{|c|}{$\%$} \\
\hline & Obj 1 & Obj 2 & Obj 3 & Obj 1 & Obj 2 & Obj 3 \\
\hline $\begin{array}{l}\text { Thermal insulation of non-transparent } \\
\text { enclosures }\end{array}$ & 71 & 54,5 & 47,8 & 20 & 16,7 & 18,3 \\
\hline $\begin{array}{l}\text { Replacement of double glazing to triple: } \\
\text { - Because of increase of thermal } \\
\text { resistance }\end{array}$ & 20,5 & 9,3 & 4,7 & 5,77 & 2,85 & 1,8 \\
\hline $\begin{array}{l}\text { - Because of decrease of non-organised } \\
\text { air exchange }\end{array}$ & 6,57 & 5,2 & 4,3 & 1,85 & 1,6 & 1,65 \\
\hline Utilisation of exhaust air heat & 66,6 & 53,3 & 45,9 & 18,7 & 16,34 & 17,58 \\
\hline $\begin{array}{l}\text { Installation of mixers with the left } \\
\text { arrangement of the crane of hot water } \\
\text { and cranes with adjustable pressure }\end{array}$ & 0,25 & 0,257 & 0,6 & 0,07 & 0,079 & 0,23 \\
\hline Account of household heat ingress & 52,6 & 77,1 & 51,4 & 14,8 & 23,6 & 19,68 \\
\hline $\begin{array}{l}\text { Account of heat ingress from solar } \\
\text { radiation through windows }\end{array}$ & 4,3 & 5,53 & 2,8 & 1,2 & 1,7 & 1,07 \\
\hline In all & 223 & 205 & 158 & 56 & 63 & 60,5 \\
\hline
\end{tabular}

without any energy saving measures. The envelope of the building was designed to meet the requirements of [8] without using its updates ${ }^{1} 3$ (1995) and ${ }^{1} 4$ (1998). The values were calculated at the temperature of the coldest day [9].

The thermal resistance of exposed walls in object 2 is higher than the same in object 1 and 3 because object 2 is a building with a higher category of thermal protection [8].

The alternative variant (var. 4) for analysis provides some technical innovations, such as:

- additional thermal insulation of solid exposed walls, roofs etc;

- triple glazing instead of a double one;

- exhaust air energy recovery with an intermediate liquid;

- installation of mixers with left-hand position of hot water taps and variable pressure taps;

- installation of thermostats on supply feeds of radiators.

Most of these engineering solutions are also very often used outside Russia. They seem to be quite ordinary in Europe. Particularly the ideas of using new effective windows were considered [10]. The recovery of exhaust air heat was described in [11]. But we have to notice that the article [11] deals with issues of using rotary heat exchangers. This way of engineering systems design is still not fully acceptable in Russia because of a very high price of some types of energy saving equipment compared with a cost of heat energy in Russia. Nevertheless, different ways of power consumption downsizing are well-known for Russian engineers, developers and contractors. It seems to be a quite ordinary engineering solution to install heat pump for hot water supply [12], using solar energy for engineering system of building etc. But most of these ideas are still in a phase of experimental design and we are not considering them now.

\subsection{The estimation of energy consumption and investments}

The energy efficiency estimation of a building is realised by calculation of its operating energy characteristics. It is equal to specific total expenses of thermal and electrical energy, $\mathrm{kWh} /\left(\mathrm{m}^{2} \cdot\right.$ year $)$, per $1 \mathrm{~m}^{2}$ of building heated space for one winter period in an annual cycle of maintenance without taking into consideration heat income provided by people, electrical devices and solar heat energy.

Heat resistance for solid walls after additional insulation was calculated according to guidelines [13] taking into the consideration $n=r_{1} / r_{2}$ ratio equal to 1 . Here $r_{1}$ and $r_{2}$ are thermal uniformity factors before and after additional insulation works. Additional investments into insulation materials come to $850 \mathrm{RUB} / \mathrm{m}^{3}$ (rockwool slab with density of $125 \mathrm{~kg} / \mathrm{m}^{3}$ ), other works and materials come to $90 \mathrm{RUB} / \mathrm{m}^{2}$. Thermal conductivity of a heat-insulated material was accepted as $0,042 \mathrm{~W} /(\mathrm{m} \cdot \mathrm{K})$.

Here we have to notify that received values of heat resistance of non-transparent external enclosures are a bit lower than recommended ones for such type of buildings in Moscow by Table 15 [8] $\left(3,15 \mathrm{~m}^{2} \cdot \mathrm{K} / \mathrm{W}\right.$ for the external wall, 4,15 for the floor over the basement, and 4,7 for the roof) and they are often much closer to values from Table $1 \mathrm{~A}$ [8] which shows only the former requirements for additional thermal insulation. They were actual before the year $2000\left(1,8 ; 2,5\right.$ and $2,85 \mathrm{~m}^{2} \cdot \mathrm{K} / \mathrm{W}$ correspondingly).

It should be mentioned that the harmful collateral consequences of excessive thermal insulation of non-transparent building elements were scoped before, for example, in [14]. The temperature efficiency of heat recovery equipment in all cases was equal to 0,5 , ie close to a maximum for the given way. The calculations of heat recovery costs 
were based on the data of equipment manufacturers and on an approximate air flow in ventilation systems of such buildings. The approximate value of the heat recovery equipment costs was assessed at a rate of about $1 / 3$ from costs of the same dimension-type ventilation unit, and expenses on mounting and adjustment - at a rate of $50 \%$ of the cost of accessories.

Heat output and costs of heating systems were calculated according to a new value of heat losses after additional insulation of exterior enclosures. The cost of radiator thermostats and other accessories is considered in total capital costs of systems. The costs of mounting and adjustment unit were assessed at a rate of $30 \%$ of the thermostats cost.

In the analysis of var 2, for all objects $90 \mathrm{~W}$ per person was taken as the indoor heat income with inclusion of heat incomes from electrical equipment, lamps etc according to real everyday usage period. All internal heat generation values of different indoor sources approximated to $10 \mathrm{~W} / \mathrm{m}^{2}$. Var 1 does not provide an automatic control of energy consumption and does not allow tweaking of systems work according to actual indoor air conditions and current heat income.

\section{Results and discussion}

\subsection{Comparative efficiency of energy saving measures}

Table 1 shows absolute energy indexes in basic (var 1) and in advanced (var 2) variants for all objects; Table 2 shows the comparative energy saving efficiency in var 2 in comparison to var 1 for the same objects. As evident from a Table's portion of every single energy saving measure into the whole energy saving results is different. But there is a similar tendency for all 3 objects. Total energy savings are

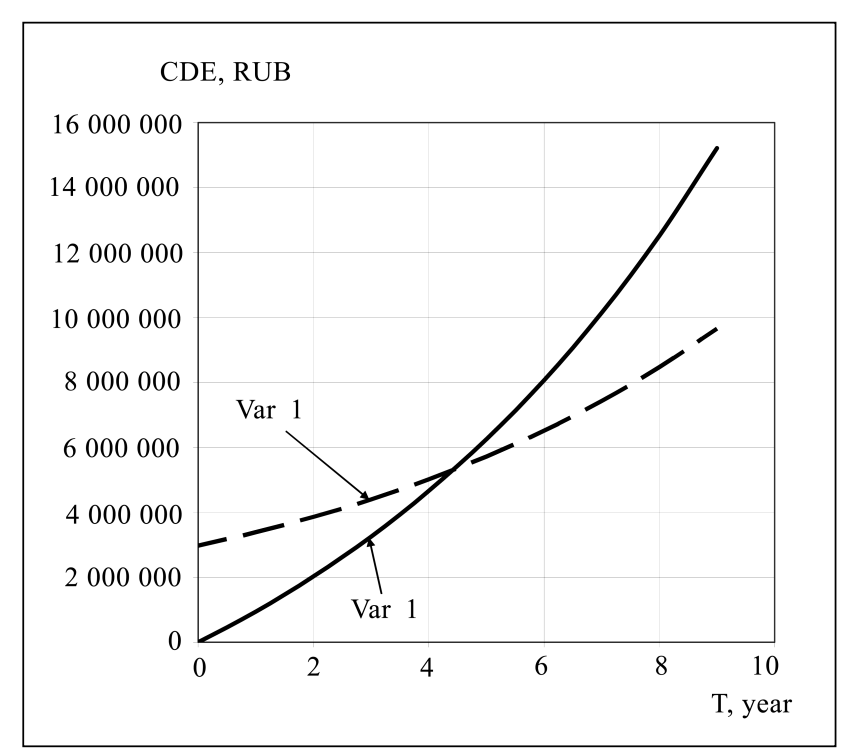

Dependence of combined expenditure discounting CDE on horizon or discounting $\mathrm{T}$ high and results are close (56-63\%) for all types of buildings. Portion of solid walls additional insulation in the whole result is not so important (16-20\%).

\subsection{Economic efficiency of all measures}

The greatest interest, however, is given to economic efficiency of all energy saving measures package. Under today's market conditions of all Russia it will be much better to make all calculations by the methods with combined expenditure discounting (CDE), RUB. In that case all factors, such as the rise of energy costs, inflation, financial risks, etc could be taken into consideration.

CDE depends on investments into energy saving $I$, annual operating expenditures $O$, and discounting limit $T$ [19]

$$
C D E=I \cdot(1+p / 100)^{T}+O \cdot\left[(1+p / 100)^{T}-1\right] \cdot(100 / p) .
$$

The term $T$ is considered as time from the date of a building operation start. CDE uses the information about prices of energy in Moscow in the second half of 2004 according to [20]. Thus the discount norm $p$ was accepted equal to the Russian Federation Central Bank rate since 15012004 or $14 \%$ annually.

For the estimation correctness it is necessary to consider [19] that purchase and installation of additional accessories are paid by borrowed funds. In this case it is possible to reveal the limits of affordability. In some cases it could be better to invest into energy saving measures (for example, in case annual energy saving income would exceed annual loan payments). In some other cases, it could be better to invest funds differently.

The results for object 2 are shown in Fig. It is easy to see that an expected recovery term of all used complex of energy saving measures even using the discount of expenses makes only 4,4 years. It is shorter than the planned life of a building (not less than 25 years). Similar data have been got as a result of analysis of objects 1 and 3. Payback term for these buildings could be about 4,1 and 2 years.

It is necessary to notice that the recovery terms of everyone separately taken measure can essentially differ from the given figures, could be both smaller and bigger. The analysis of the data [21] shows that the cheapest measure is application of heat recovery in ventilating systems and automation of the heating ones.

For comparison, reduced in the enclosure $\Gamma$ [22] rules of energy consumption calculus for the heating season leave unaccounted many possible energy saving measures, ie exhaust air energy recovery, using the heat pumps and many others. Besides, the permissible decrease of thermal resistance of a building envelope (for outside walls - up to $37 \%$, for floors and ceilings - only $20 \%$ ) does not reach values, sufficient to meet the sanitary-hygienic requirements. Furthermore, as stated in [8], the other components of an energy balance of a building include the heated consumption 
on heat water supply, electric power consumption etc. Thus the technique of the standard [7] allows for all these circumstances and gives the designer maximum capabilities for implementing the energy saving measures.

Table 2 shows that the comparative decrease of energy consumption provided by extra thermal insulation and of heat recovery is close and makes approx 16-20\%. But the cost for heat recovery is essentially lower. The effect of the thermostats installation is also within the same limits.

A little bit smaller effect (5-10\%) is achieved by the replacement of a glazing. At the same time minor economies from the maintenance of hot water supply system in the given series of objects were received because the normative consumption of hot water in office buildings is very small. However, in housing these measures can give a better effect because of a high portion of hot water supply systems in the common energy balance (up to 30-35\%). Thus the energy saving potential of each measure in different buildings appears to be rather close, and they differ only because of different areas of the walls, windows, floors and roofs.

Great additional thermal insulation of walls, roofs and floors seems to be economically unjustified under market conditions of Russia because the annual percent are for the credit taken for additional insulation will be higher than the expected annual saving of expenses on thermal energy, as shown [19].

Nevertheless, the project of building absolutely without any additional heat insulation is not acceptable, because other ways of energy saving, as a rule, do not provide desirable total decrease of energy consumption. But such decrease should be performed in reasonable limits [21] and after a complex analysis of energy saving potential of other possible measures. Therefore only the complex approach to energy saving is capable to sort out a problem of deficiency of energy resources, staying in economically effective range.

\section{Conclusions}

Thus now for the first time and using examples of the real buildings the complex technique of building heat protection choice and method of their energy efficiency estimation are offered. Also, the technique offered in the standard of Rus. Sci. Tech. C. E. O. [7] is realized. It was affirmed as convenient to the engineering practice. Besides, the quantitative assessment of absolute and relative efficiency of separate energy saving measures and of their entire complex was obtained. Reasons of the authors concerning the standard [7] about an optimum level of thermal insulation of walls, roofs and floors [13], [19] and most expedient sequence of other energy saving measures [21] were also affirmed.

The technique of energy efficiency analysis, developed in Rus. Sci. Tech. C. E. O., allows to accept decisions on heat protection and construction of engineering systems already during the feasibility study of the project. At first main parameters of the project, ie the distribution of energy expenditures, should be defined. Then by a subsequent detailed development of separate sections of the project (heat-shielding, heating, ventilation, hot water supply system etc) they may be defined more exactly. Only in this case it is possible to overcome inconsistency between functioning of various engineering systems of a building and to ensure interchangeability within limits of all ways of energy saving with minimal expenses.

\section{References}

1. MARTINAITIS, V.; ROGOŽA, A.; BIKMANIENE, I. Criterion to evaluate the "Twofold benefit" of the renovation of buildings and their elements. Energy and Buildings, 2004, Vol 36, p. 3-8.

2. KAKLAUSKAS, A.; ZAVADSKAS, E. K.; RASLANAS, S. Multivariant design and multiple criteria analysis of building refurbishments. Energy and Buildings, 2005, Vol 37 (4), p. 361-372.

3. PAULAUSKAITÉ, S.; MARTINAITIS, V. Efficiency of schools renovation in Lithuania (Effizienz bei einer Schulrenovation in Litauen). In E-nova, International Congress, Anwendung der moderner EDV-Technologien in der Gebaude- und Energietechnik, 18-19 Nov 2004, Pinkafeld, Austria. Proceedings of the Conference, Redaction: Gortler G., Graf M., Studienzentrum Pinkafeld, p. 239-252 (in German).

4. MARTINAITIS, V.; ŠIUPŠINSKAS, G. Reduction of operation and maintenance expenditures by the consequent planning at Palanga rehabilitation hospital. International Journal of Strategic Property Management, 2003, Vol 7, No 2, p. 96105.

5. ČIUPRINSKAS, K.; MARTINAITIS, V. Correction of a designed building's heat balance according to its real heat consumption. Journal of Civil Engineering and Management, 2003, Vol IX, No 2, p. 98-103.

6. SAMARIN, O. D.; BARVINSKY, S. Y.; ANISIMOV, A. I.; SADIKOVA, I. R. On a problem of efficiency estimation of energy saving measures under the conditions of free enterprising (К вопросу оценки эффективности энергосберегающих мероприятий в условиях рыночной экономики). In Proceedings of the International Sci. and Tech. Forum "Theoretical foundations of heat and gas supply and ventilation", Moscow, 2006, p. 25-28 (in Russian).

7. National voluntary consensus standard. The norms of heat protection designing of building enclosures and estimation of energy efficiency of buildings (Стандарт организации. «Нормы теплотехнического проектирования ограждающих конструкций и оценки энергоэффективности зданий»). Moscow: Rus. Sci. Tech. C. E. O, 2006 (in Russian).

8. Design code II-3-79* Building thermal physics (СНиП Строительная теплотехника). Moscow: State Committee of Civil Engineering, 1998 (in Russian).

9. Design code (СНиП) 23-01-99 Building climatology (СНиП Строительная климатология). Moscow: State Committee of Civil Engineering, 2000 (in Russian). 
10. BURLINGIS, A.; SAMAJAUSKIENĖ, B.; RAMANAUSKAS, J. An influence of outdoor temperature on thermal performance of windows with a low-emissivity glazing. Journal of Civil Engineering and Management, 2003, Vol IX, No 2, p. 115-121.

11. RAMANAUSKAS, R. Efficient use of rotary heat exchangers. In Energy for buildings, The $6^{\text {th }}$ international conference on Energy for Buildings, Oct 7-8, 2004, Lithuania / Proc of the Conference, Editors: Abel E., Martinaitis V., Todorovic B. Vilnius: Technika, p. 360-366. ISBN 9986-05-771-X.

12. PETRAŠ, D.; MATEJ, P. The optimization of the heat pump operation in low-temperature heating systems. In Energy for buildings, The $6^{\text {th }}$ international conference on Energy for Buildings, Oct 7-8, 2004, Lithuania / Proc of the Conference, Editors: Abel E., Martinaitis V., Todorovic B. Vilnius: Technika, p. 346-351. ISBN 9986- 05-771-X.

13. IVANOV, G. S. The procedure of optimizing the level of building heat protection. Walls and facades (Стены и фасады), 2001, No 1-2, p. 7-10 (in Russian).

14. ABRAHAMSSON, M. Interacting energy solutions lower the energy demand in buildings. In Energy for buildings, The $4^{\text {th }}$ international conference/Proc of the Conference. Vilnius, Lithuania, 21-22 Sept, 2000. Vilnius: Litimo, p. 207-214.

15. Design code (СНиП) 2.08.02-89 Public buildings and structures (Общественные здания и сооружения). Moscow: State Committee of Civil Engineering, 1999 (in Russian).

16. ISO 7730:1994 Moderate thermal environments - Determi- nation of the PMV and PPD indices and specification of the conditions for thermal comfort. Gèneve, 1994. $27 \mathrm{p}$.

17. Design code (СНиП) 2.04.01-85 Internal water supply and sewerage of buildings (Внутренний водопровод и канализация зданий). Moscow: State Committee of Civil Engineering, 2000 (in Russian).

18. Department design code (BCH) 59-88 Electric equipment of residential and public buildings (Электрооборудование жилых и общественных зданий). Moscow: State Architectural Committee, 1988 (in Russian).

19. GAGARIN, V. G. Criterion of expense recovery for increase of a heat-shielding of protecting designs of buildings in various countries (Критерий окупаемости затрат на повышение теплозащиты ограждающих конструкций зданий в различных странах). Paper of conference of Rus. Sci. Tech. C. E. O., 2001, p. 43-63 (in Russian).

20. Moscow municipal design code (МГСН) 2.01-99 Energy saving in buildings (Энергосбережение в зданиях). Moscow: Municipal Architectural Committee, 1999 (in Russian).

21. SAMARIN, O. D. Comparative effectiveness of energy saving measures (Сравнительная эффективность энергосберегающих мероприятий). In Proc of the 6th Moscow International Forum "Heat \& Vent 2004", 2004 p. 21-25 (in Russian).

22. Design code (СНиП) 23-02-2003 Thermal protection of buildings (Тепловая защита зданий). Moscow: State Committee of Civil Engineering, 2003 (in Russian).

\section{ENERGIJOS TAUPYMO EFEKTYVUMAS VISUOMENINĖS PASKIRTIES PASTATUOSE RUSIJOJE RINKOS EKONOMIKOS SĄLYGOMIS}

\section{O. Samarin, K. Lushin, S. Paulauskaitė}

\section{Santrauka}

Išnagrinètas vienas iš grupès energiją taupančiu priemonių kompleksinio efektyvumo įvertinimo variantu viešosios paskirties pastatuose, taikant Rusijos statybininkų mokslinès techninès draugijos (PHTO) projekto visuomeninio standarto metodiką. Nustatytos pagrindinès šiluminès ir elektros energijos išlaidų sudedamosios dalys, reikalingos grupès tirtų pastatų inžinerinès struktūros funkcionavimui. Duota taikytų priemonių energijos taupymo potencialo lyginamoji analizè. Pateikti siūlomų inžinerinių sprendimų komplekso atsipirkimo laiko skaičiavimai rinkos ekonomikos sąlygomis, Ł̇vertinant kapitalinių ir eksploatacinių išlaidų diskonto normą.

Reikšminiai žodžiai: energijos taupymas, lyginamasis efektyvumas, kompleksinis požiūris, išlaidų mažinimas.

Oleg SAMARIN. Associate Professor. Dept of Heating and Ventilation, Moscow State Civil Engineering University. Research interests: thermal indoor air conditions, indoor air quality and flows, engineering systems controls and automation, energy saving.

Kirill LUSHIN. Assistant, Engineer. Dept of Heating and Ventilation, Moscow State Civil Engineering University. Research and business interests: engineering systems automation, HVAC systems mathematical modelling and design optimisation, CAD in HVAC field, staff training and recruitment in HVAC.

Sabina PAULAUSKAITE். Associate Professor, Doctor. Dept of Heating and Ventilation, Vilnius Gediminas Technical University. Research interests: microclimate parameters estimation in premises, heat and moisture behaviour in building envelopes, buildings and engineering systems energy assessment. 